\title{
EFEKTIVITAS KOLABORASI QR CODE DAN EDMODO (QRCE) TERHADAP MOTIVASI SERTA HASIL BELAJAR MATERI KONSEP MOL PADA SISWA KELAS X SMK KESEHATAN PURWOREJO TAHUN PELAJARAN 2018/ 2019
}

\author{
Diah Megasari Tyasning ${ }^{1}$ dan Arini Fadhilah ${ }^{2}$ \\ ${ }^{1}$ SMK Kesehatan Purworejo, Purworejo, 54114 \\ Email Korespondensi: diah_mega83@yahoo.co.id
}

Diajukan: 7 January 2020; Diterima: 10 February 2020; Diterbitkan: 30 April 2020

\begin{abstract}
Abstrak: Penelitian ini bertujuan untuk mengetahui adakah perbedaan motivasi dan hasil belajar siswa yang menggunakan kolaborasi QRCE dan pembelajaran konvensional pada materi konsep mol. Penelitian dilakukan pada bulan Februari hingga Juli 2019. Populasi dalam penelitian ini meliputi siswa kelas X SMK Kesehatan Purworejo tahun pelajaran 2018/ 2019 yang terdiri dari 5 kelas. Jenis penelitian yang digunakan adalah non randomized pre-test and post-test control group. Pengambilan sampel dilakukan dengan menggunakan teknik cluster random sampling. Sampel terdiri dari dua kelas yaitu kelas X Farmasi 1 (kontrol) dan X Farmasi 2 (eksperimen). Teknik pengumpulan data menggunakan teknik tes dan angket. Teknik analisis data untuk uji hipotesis dilakukan dengan tes nonparametrik Mann-Whitney. Dari hasil penelitian dan analisis yang telah dilakukan menunjukkan: 1) Ada perbedaan motivasi belajar siswa yang menggunakan kolaborasi QRCE dan pembelajaran konvensional pada materi konsep mol dibuktikan dengan nilai signifikansi untuk motivasi belajar 0,030. 2) Ada perbedaan hasil belajar siswa yang menggunakan kolaborasi QRCE dan pembelajaran konvensional pada materi konsep mol dibuktikan dengan nilai signifikansi sebesar 0,024.
\end{abstract}

Kata kunci : $Q R$ Code, Edmodo, Motivasi dan Hasil Belajar

Abstract: This study aims to determine whether there are differences in student motivation and learning outcomes using QRCE collaboration and conventional learning on the mole concept material. The study was conducted from February to July 2019. The population in this study included class X SMK Kesehatan Purworejo 2018/2019 academic year which consisted of 5 classes. The type of research used is a non-randomized pre-test and post-test control group. Sampling was done by using cluster random sampling technique. The sample consisted of two classes, namely class X Pharmacy 1 (control) and X Pharmacy 2 (experimental). Data collection techniques using test and questionnaire techniques. The data analysis technique for hypothesis testing was carried out by the MannWhitney nonparametric test. From the results of research and analysis that have been carried out, it shows: 1) There are differences in student motivation using QRCE collaboration and conventional learning on the mole concept material as evidenced by a significance value for learning motivation of 0.030. 2) There are differences in student learning outcomes using QRCE collaboration and conventional learning on the mole concept material as evidenced by a significance value of 0.024 .

Keywords: QR Code, Edmodo, Motivation and Learning Outcomes

\section{Pendahuluan}

Perkembangan teknik informatika dan komputer yang semakin pesat membawa dampak terhadap dunia pendidikan saat ini. Di sisi lain, berubahnya paradigma pendidikan yang dulunya menganut teacher-centered learning menjadi student-centered learning, membawa perubahan yang sangat signifikan terhadap metode-metode pembelajaran yang dikembangkan saat ini (Darmawan, 2018). Salah satu metode pembelajaran yang sedang dikembangkan adalah pembelajaran 4.0 yang merupakan respon dari revolusi industri 4.0 dimana manusia dan teknologi diselaraskan untuk memungkinkan kemungkinankemungkinan baru. Teknologi menjadi alat pendukung yang memainkan peran penting dalam praktik pendidikan oleh guru dan siswa.Mengintegrasikan salah satu teknologi ke dalam pengajaran dan pembelajaran sehari-hari telah menjadi persyaratan pendidikan abad ini (Al. Ruheili, 2015). Pendidikan 4.0 merupakan pendidikan yang bercirikan pemanfaatan teknologi digital dalam proses pembelajaran atau dikenal dengan sistem siber (cyber system). Sistem ini mampu membuat proses 
pembelajaran dapat berlangsung secara kontinu tanpa batas ruang dan waktu (Darmawan, 2018).

Salah satu usaha yang dapat dilakukan untuk memenuhi tren tersebut adalah dengan memanfaatkan smartphone dalam proses pembelajaran. Salah satu aplikasi smartphone yang bisa digunakan sebagai media pembelajaran adalah aplikasi edmodo. Edmodo dikembangkan pada akhir tahun 2008 oleh Nick Borg dan Jeff O"Hara (Hourdequin, 2014). Edmodo merupakan jejaring sosial yang mudah untuk digunakan dalam menyajikan materi pelajaran, sehingga siswa dan guru dapat berinteraksi secara online di luar kelas ataupun dimana saja, kapan saja (Balasubramanian, 2014). Edmodo memiliki tampilan dan fitur yang mengikuti perkembangan tampilan dari media jejaring sosial facebook yang populer digunakan oleh para siswa. Selain bisa digunakan untuk media pembelajaran, edmodo juga dapat digunakan sebagai alat evaluasi yang praktis dan efektif tanpa harus menggunakan kertas.

Selain itu edmodo telah menempati peringkat sebagai salah satu alat pembelajaran teratas oleh lima ratus lebih profesional dari 48 negara di seluruh dunia (Enriquez, 2014). Edmodo digunakan setiap hari oleh lebih dari lima puluh juta guru dan siswa di seluruh dunia (Situs Web Edmodo, 2015). Studi terbaru dalam konteks pendidikan yang berbeda telah membuktikan efektivitasnya sebagai bantuan untuk melengkapi interaksi kelas tatap muka (Al-Said, 2015; Al-Kathiri, 2015; Enriquez, 2014).

Hasil penelitian penggunaan situs jejaring sosial edmodo di lingkungan universitas oleh Enriquez (2014) diperoleh bahwa situs jejaring sosial edmodo baik digunakan sebagai alat tambahan bagi pembelajaran di kelas karena memungkinkan mahasiswa untuk meningkatkan belajar mereka melalui partisipasi aktif dalam diskusi online. Penelitian yang dilakukan Wijaya, dkk. (2019) mendapatkan hasil ada pengaruh strategi pembelajaran berbasis digital menggunakan edmodo terhadap hasil belajar siswa sebesar $52,8 \%$. Hasil penelitian yang dilakukan Dewi (2014) menyatakan bahwa siswa menunjukkan kemajuan yang positif dengan menggunakan edmodo dalam pembelajarannya. Selain itu siswa juga merasa lebih nyaman melakukan diskusi secara online bersama teman dan gurunya.

Selain edmodo, ada aplikasi berbasis smartphone yang dapat menunjang aktivitas siswa dalam proses pembelajaran, yaitu $Q R$ code. $Q R$ code adalah image dua dimensi yang merepresentasikan suatu data, terutama data berbentuk teks. $Q R$ code merupakan evolusi dari barcode yang awalnya satu dimensi menjadi dua dimensi. $Q R$ code berisi informasi baik diarah vertikal dan horizontal, sedangkan barcode berisi data dalam satu arah saja (Narayanan, 2012). Aplikasi $Q R$ reader untuk berbagai macam tipe ponsel cukup banyak tersedia untuk diunduh secara gratis melalui internet (Ridwan, dkk. 2010) sehingga siswa dapat dengan mudah menggunakannya.

Berdasarkan hasil observasi yang dilakukan di SMK Kesehatan Purworejo didapatkan hasil: 1) siswa merasa pelajaran kimia yang merupakan pelajaran sukar untuk dipahami. 2) motivasi belajar siswa yang rendah terhadap pelajaran kimia. 3) siswa menginginkan pembelajaran kimia yang tidak monoton/ bukan pembelajaran konvensional. 4) pengaruh dari jejaring sosial kadang membuat siswa mengabaikan tugas-tugas sekolah. 5) siswa diperbolehkan membawa smartphone ke sekolah, namun pemanfaatan smartphone untuk menunjang proses pembelajaran masih kurang mendaatkan perhatian. 6) siswa memiliki fasilitas wiFi yang dapat dimanfaatkan untuk menunjang proses belajar di sekolah.

Berdasar latar belakang tersebut peneliti tertarik untuk mengkolaborasikan $Q R$ Code dan edmodo dalam pembelajaran kimia khususnya materi konsep mol. Tujuan dari penelitian ini adalah untuk mengetahui adakah perbedaan motivasi dan hasil belajar siswa yang menggunakan kolaborasi $Q R$ Code dan edmodo (QRCE) dan pembelajaran konvensional pada materi konsep mol.

\section{Perumusan Masalah}

Permasalahan dalam penelitian ini dapat dirumuskan sebagai berikut: (1) Adakah perbedaan motivasi belajar siswa yang menggunakan kolaborasi QRCE dan pembelajaran konvensional pada materi konsep mol?; (2) Adakah perbedaan hasil belajar siswa yang menggunakan kolaborasi QRCE dan 
pembelajaran konvensional pada materi konsep mol?

\section{Metode Penelitian}

Penelitian dilakukan di SMK Kesehatan Purworejo pada semester genap tahun pelajaran 2018/ 2019. Jenis penelitian yang dilakukan adalah non randomized pre-test and post test control group yaitu suatu penelitian yang dilakukan dengan dua kelompok tanpa randomisasi, satu kelompok diberi perlakuan dengan kolaborasi QRCE dan kelompok lain sebagai kontrol, kemudian diobservasi sebelum dan sesudahnya.

Populasi dalam penelitian ini adalah siswa Kelas X SMK Kesehatan Purworejo tahun pelajaran 2018/ 2019 yang berjumlah 5 kelas dengan jumlah siswa sebanyak 131 siswa. Pengambilan sampel dilakukan dengan teknik cluster random sampling. Dari 5 kelas yang dijadikan populasi diambil dua kelas secara random (acak) untuk dijadikan sebagai kelompok sampel. Syarat agar dapat dilakukan pengambilan sampel secara acak adalah tidak ada perbedaan hasil belajar yang signifikan dari kelas-kelas yang dijadikan populasi. Untuk itu dilakukan uji kesamaan rata-rata dengan PASW 18 dan didapatkan nilai signifikansi sebesar 0,063 yang artinya tidak ada perbedaan hasil belajar yang signifikan antara 5 kelas yang dijadikan populasi. Selanjutnya dilakukan pengambilan sampel secara acak dan didapatkan kelas X Farmasi 1 sebagai kelas kontrol yang menggunakan metode pembelajaran konvensional dan X Farmasi 2 sebagai kelas eksperimen yang pembelajarannya menggunakan kolaborasi QRCE.

Sebelum pembelajaran dilakukan terlebih dahulu diberikan pretes untuk mengetahui motivasi dan pengetahuan dasar siswa pada materi Konsep Mol. Setelah pembelajaran berlangsung siswa diberi postes untuk selanjutnya peneliti dapat mentukan $n$ gain dari masing-masing kelas. Uji hipotesis dilakukan dengan membandingkan nilai $n$-gain dari kelas kontrol dan kelas ekserimen menggunakan uji nonparametrik KruskallWallis. Variabel bebas dalam penelitian ini adalah metode pembelajaran yang diterapkan, yaitu pembelajaran konvensional untuk kelas kontrol dan pembelajaran menggunakan kolaborasi QRCE untuk kelas eksperimen.
Sedangkan variabel terikat dalam penelitian ini adalah motivasi dan hasil belajar pada aspek pengetahuan.

Teknik pengumpulan data menggunakan metode tes dan angket. Metode tes dijadikan acuan untuk mengetahui hasil belajar dan nilai uasaha siswa pada aspek pengetahuan. Sedangkan angket digunakan untuk mengetahui seberapa besar pengaruh penerapan kolaborasi QRCE terhadap motivasi belajar siswa.

\section{Hasil Penelitian dan Pembahasan}

\section{Data penelitian}

Data hasil belajar didapat dari jawaban soal pretes dan postes yang berupa soal pilihan ganda sebanyak 10 soal dengan rentang nilai 0 - 100. Data motivasi belajar didapat dari jawaban angket sebanyak 30 soal dengan rentang nilai $30-120$. Angket yang digunakan berupa angket tertutup yang mengacu pada skala Likert dengan empat pilihan jawaban yaitu sangat setuju, setuju, tidak setuju dan sangat tidak setuju. Dari nilai pretes dan postes dihitung n-gain nya dengan rumus:

$$
=\frac{\begin{array}{l}
\text { Normalized gain } \\
\text { nilai postest-nilai pretest }
\end{array}}{\text { nilai maksimum-nilai pretest }}
$$

\section{Data Motivasi Belajar}

Dalam penilaian didapatkan nilai terendah 68 dan nilai tertinggi 119 dari rentang nilai 30-120. Penilaian dilakukan sebanyak 2 kali. Penilaian pertama adalah pretes, penilaian kedua adalah postes, selanjutnya dihitung $n$ gainnya. Secara umum deskripsi data $n$-gain dari motivasi belajar dapat dilihat pada Tabel 1.

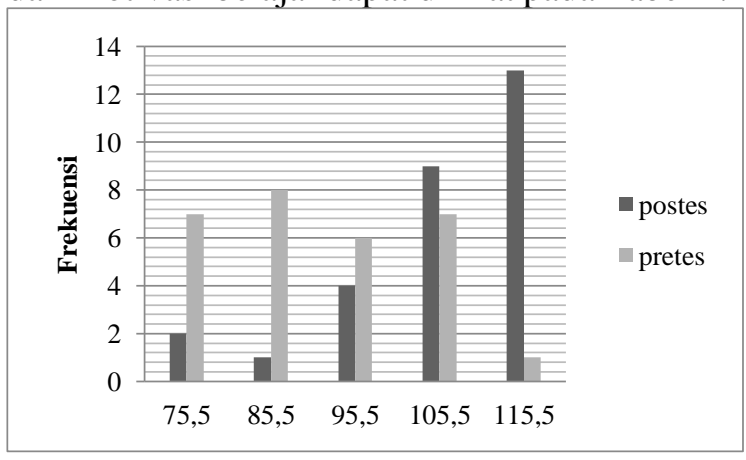

Gambar 1. Histogram Distribusi Frekuensi Nilai Motivasi Belajar Kelas Kontrol 


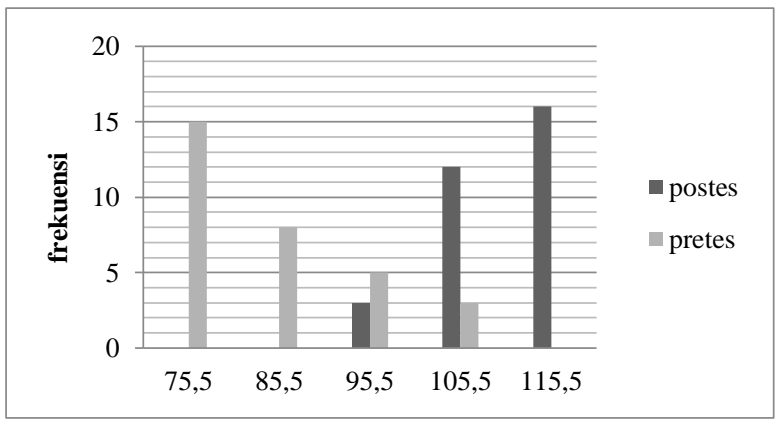

Gambar 2. Histogram Distribusi Frekuensi Nilai Motivasi Belajar Kelas Ekperimen

Tabel 1. Data n-gain dari motivasi belajar

\begin{tabular}{cccccc}
\hline $\begin{array}{c}\text { Kelompok } \\
\text { kelas }\end{array}$ & $\begin{array}{c}\text { Jumlah } \\
\text { Data }\end{array}$ & $\begin{array}{c}\text { Nilai } \\
\text { Minimum }\end{array}$ & $\begin{array}{c}\text { Nilai } \\
\text { Maksimum }\end{array}$ & $\begin{array}{c}\text { Rata- } \\
\text { rata }\end{array}$ & SD \\
\hline Kontrol & 29 & 0 & 1 & 0,50 & 0,34 \\
\hline Eksperimen & 31 & 0,13 & 1 & 0,69 & 0,22 \\
\hline
\end{tabular}

\section{Data Hasil Belajar}

Dalam penilaian didapatkan nilai terendah 20 dan tertinggi 90 dengan rentang nilali 0-100. Penilaian dilakukan sebanyak 3 kali. Penilaian pertama adalah pretes, penilaian kedua untuk mengetahui nilai usaha siswa dan penilaian ke tiga adalah postes. Secara umum deskripsi data $n$-gain dari hasil belajar dapat dilihat pada Tabel 2.

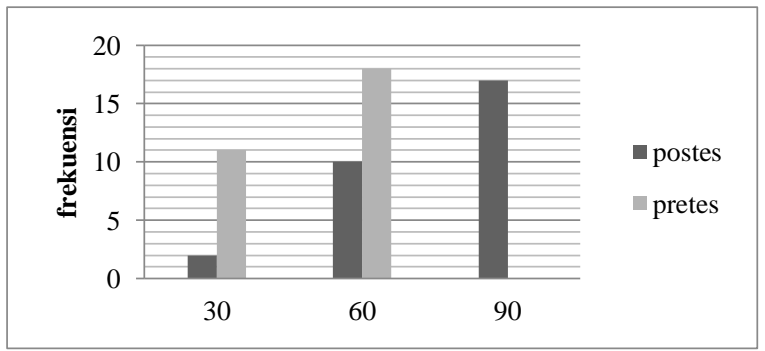

Gambar 3. Histogram Distribusi Frekuensi Hasil Belajar Kelas Kontrol

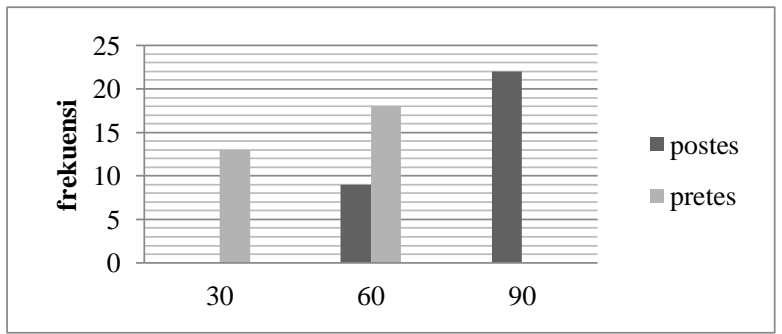

Gambar 4. Histogram Distribusi Frekuensi Hasil Belajar Kelas Eksperimen

\begin{tabular}{|c|c|c|c|c|c|}
\hline $\begin{array}{c}\text { Kelompok } \\
\text { kelas }\end{array}$ & $\begin{array}{c}\text { Jumla } \\
\text { h } \\
\text { Data }\end{array}$ & $\begin{array}{c}\text { Nilai } \\
\text { Minimu } \\
\mathrm{m}\end{array}$ & $\begin{array}{c}\text { Nilai } \\
\text { Maksimu } \\
\text { m }\end{array}$ & $\begin{array}{l}\text { Rata } \\
\text {-rata }\end{array}$ & SD \\
\hline Kontrol & 29 & 0 & 1 & 0,58 & $\begin{array}{c}0,3 \\
1\end{array}$ \\
\hline $\begin{array}{l}\text { Eksperim } \\
\text { en }\end{array}$ & 31 & 0 & 1 & 0,75 & $\begin{array}{c}0,2 \\
4\end{array}$ \\
\hline
\end{tabular}

\section{Pengujian Prasyarat Analisis}

Analisis data dilakukan dengan membandingkan $n$-gain dari kedua kelompok kelas eksperimen dan kelas kontrol. Statistik uji dilakukan dengan PASW 18. Sebelum dilakukan uji statistik terlebih dahulu dilakukan uji prasyarat analisis yaitu uji normalitas dan uji homogenitas. Uji normalitas dilakukan untuk mengetahui apakah sampel berasal dari populasi yang terdistribusi normal atau tidak. Nilai signifikansi yang digunakan mengacu pada rumus Kolmogorov-Smirnov dan dilakukan dengan PASW 18. Jika nilai signifikansi yang didapatkan lebih dari atau sama dengan 0,05 , maka $\mathrm{H}_{0}$ diterima artinya data berdistribusi normal. Uji homogenitas dilakukan dengan PASW 18. Jika didapatkan signifikansi lebih dari atau sama dengan 0,05 maka $\mathrm{H}_{0}$ diterima artinya data homogen. Jika didapatkan signifikansi kurang dari 0,05 maka $\mathrm{H}_{0}$ ditolak artinya data tidak homogen.

\section{Motivasi Belajar}

a. Uji Normalitas

Hasil uji normalitas untuk nilai motivasi belajar menunjukkan bahwa sampel berasal dari populasi yang berdistribusi normal ditunjukkan dengan nilai signifikansi lebih dari 0,05 .

Tabel 3. Hasil Uji Normalitas Data Motivasi Belajar Siswa

\begin{tabular}{ccc}
\hline Kelompok Kelas & Signifikansi & Keterangan \\
\hline Kontrol & 0,094 & Normal \\
\hline Eksperimen & 0,058 & Normal \\
\hline
\end{tabular}

b. Uji Homogenitas

Hasil uji yang didapat menunjukkan bahwa sampel untuk motivasi belajar merupakan sampel yang tidak homogen karena dari hasil perhitungan dengan PASW 18 didapatkan nilai signifikansi 0,002 (kurang dari 0,05: $\mathrm{H}_{0}$ ditolak) 


\section{Hasil Belajar}

\section{a. Uji Normalitas}

Hasil uji normalitas untuk hasil belajar menunjukkan bahwa sampel berasal dari populasi yang tidak berdistribusi normal ditunjukkan dengan adanya nilai signifikansi yang kurang dari 0,05 .

\begin{tabular}{ccc}
\multicolumn{3}{c}{ Tabel 4. Hasil Uji Normalitas Data Hasil Belajar } \\
\hline $\begin{array}{c}\text { Kelompok } \\
\text { Kelas }\end{array}$ & Signifikansi & Keterangan \\
\hline Kontrol & 0,200 & Normal \\
\hline Eksperimen & 0,029 & Tidak Normal \\
\hline
\end{tabular}

b. Uji Homogenitas

Hasil uji yang didapat menunjukkan bahwa sampel untuk hasil belajar merupakan sampel yang homogen. Hal ini berdasar hasil perhitungan dengan PASW 18 didapatkan nilai signifikansi 0,088 (lebih dari 0,05: $\mathrm{H}_{0}$ diterima).

\section{Pengujian Hipotesis}

Pengujian hipotesis menggunakan uji statistik nonparametrik Mann-Whitney karena data yang diperoleh berasal dari populasi yang tidak berdistribusi normal sehingga tidak memenuhi syarat untuk dilakukan uji dengan statistik parametrik. Hasil uji hipotesis menggunakan statistik nonparametrik disajikan dalam Tabel 5.

Tabel 5. Hasil Uji Statistik Non Parametrik Mann-Whitney

\begin{tabular}{ccc}
\hline Uji Hipotesis & Nilai Signifikansi & Keterangan \\
\hline Hipotesis 1 & 0,024 & Ada perbedaan \\
\hline Hipotesis 2 & 0,030 & Ada perbedaan
\end{tabular}

Hasil pengujian hipotesis menggunakan uji statistik non parametrik Mann-Whitney dalam penelitian ini dapat disimpulkan sebagai berikut:

\section{Uji Hipotesis Pertama}

Hipotesis pertama dalam penelitian adalah sebagai berikut:

Tidak ada perbedaan motivasi belajar

$\mathrm{H}_{0}$ : siswa yang menggunakan kolaborasi QRCE dan pembelajaran konvensional pada materi konsep mol.

Ada perbedaan motivasi belajar siswa

$\mathrm{H}_{1}$ : yang menggunakan kolaborasi QRCE dan pembelajaran konvensional pada materi konsep mol.
Berdasarkan hasil uji didapatkan nilai signifikansi untuk motivasi belajar 0,030 (kurang dari 0,05: $\mathrm{H}_{0}$ ditolak) artinya ada perbedaan motivasi belajar siswa kelas kontrol dengan kelas eksperimen.

\section{Uji Hipotesis kedua} adalah:

Hipotesis kedua dalam penelitian ini Tidak ada perbedaan hasil belajar siswa $\mathrm{H}_{0}$ : yang menggunakan kolaborasi QRCE dan pembelajaran konvensional pada materi konsep mol.

Ada perbedaan hasil belajar siswa yang $\mathrm{H}_{1}$ : menggunakan kolaborasi QRCE dan pembelajaran konvensional pada materi konsep mol.

Berdasarkan hasil uji didapatkan signifikansi hasil belajar 0,024 (kurang dari 0,05: $\mathrm{H}_{0}$ ditolak) artinya ada perbedaan hasil belajar siswa yang menggunakan kolaborasi QRCE dengan pembelajaran konvensional pada materi konsep mol.

Berdasar hasil uji hipotesis yang telah dilakukan dapat dijelaskan masing-masing hasil uji hipotesis sebagai berikut:

\section{Hipotesis Pertama}

Berdasarkan hasil uji statistik didapatkan hasil bahwa ada perbedaan motivasi belajar siswa yang menggunakan kolaborasi QRCE dan pembelajaran konvensional pada materi konsep mol. Dari histogram pada Gambar 1, terdapat peningkatan motivasi belajar siswa pada kelas kontrol. Namun peningkatan tersebut kurang signifikan jika dibandingkan dengan histogram pada Gambar 2. Pada Gambar 2 motivasi belajar siswa mengalami peningkatan secara signifikan setelah penggunaan kolaborasi QRCE pada kegiatan pembelajaran. Penelitian sejenis yang dilakukan oleh Marie dan Esther (2019) juga menyebutkan bahwa penggunaan edmodo dalam pembelajaran dapat meningkatkan motivasi belajar siswa.

Pembelajaran menggunakan kolaborasi QRCE diawali dengan pembelajaran tatap muka di kelas untuk memberikan informasi kepada siswa mengenai tujuan belajar dan model pembelajaran yang akan dilakukan selama mempelajari materi konsep mol. Pembelajaran menggunakan aplikasi edmodo bukan kali pertama dilakukan di kelas X SMK 
Kesehatan Purworejo tahun pelajaran 2018/2019 karena pada materi sebelumnya siswa kelas $\mathrm{X}$ ini sudah pernah menggunakan aplikasi tersebut. Hal ini menjadikan siswa tidak gagap dalam mengikuti proses pembelajaran menggunakan aplikasi edmodo. Aplikasi ini memungkinkan siswa untuk berinteraksi dengan guru maupun siswa lain dimana saja dan kapan saja jika didukung dengan koneksi internet yang baik. Pembelajaran pada kelas eksperimen ini tidak hanya dilakukan di dalam kelas, namun juga di luar kelas. Siswa menjadi tidak bosan dan dapat mengikuti pembelajaran dengan lebih santai.

Pembelajaran pada materi Konsep Mol kali ini tidak hanya menggunakan aplikasi edmodo namun juga $Q R$ Code. Penggunaan $Q R$ Code dalam pembelajaran merupakan hal yang baru bagi siswa sehingga diharapkan siswa akan semakin tertarik untuk belajar sehingga motivasi belajarnya dapat meningkat. $Q R$ Code dalam penelitian ini berfungsi dalam presensi dan pembagian kelompok siswa. Para siswa diberikan $Q R$ Code yang berisi nama mereka masing-masing. Pada kelas kontrol setiap memulai pelajaran guru akan memanggil namanama siswa satu per satu untuk mengisi daftar hadir siswa, sedangkan pada kelas eksperimen para siswa akan menunjukkan $Q R$ Code mereka masing-masing yang terdapat di smartphone dan di-scan oleh guru. Berdasar hasil wawancara dengan siswa, presensi menggunakan $Q R$ Code membuat siswa lebih semangat untuk mengikuti pelajaran karena mereka melakukan hal yang berbeda dari biasanya. Siswa mengaku merasa senang ketika guru men-scan $Q R$ Code mereka dan nama mereka masuk ke dalam presensi. Hal ini membuat siswa lebih termotivasi dalam mengikuti kegiatan pembelajaran.

Selain penggunaannya dalam presensi, fungsi dari $Q R$ Code adalah untuk pembagian kelompok. Pembagian kelompok diatur oleh guru sehingga setiap kelompok memiliki anggota dengan kemampuan kognitif yang heterogen. Pembagian kelompok yang heterogen bertujuan agar setiap siswa bisa belajar dari anggota dalam kelompoknya dan didapatkan kelompok yang kemampuannya setara antara satu kelompok dengan kelompok yang lain. Pada kelas kontrol, guru membagi siswa berdasar nilai siswa dengan membacakan nama anggota kelompok di depan kelas.
Sedangkan pada kelas eksperimen, guru telah membuat $5 Q R$ Code yang merupakan nama ketua kelompok. Ketua kelompok adalah 5 siswa yang memiliki nilai rata-rata tertinggi dalam mata pelajaran kimia. $Q R$ Code tersebut ditempelkan di tempat-tempat yang dapat terlihat di lingkungan sekolah. Tugas dari siswa yang bukan ketua kelompok adalah menemukan $Q R$ Code tersebut dan menscannya. Nama yang muncul saat siswa tersebut men-scan $Q R$ Code adalah nama ketua kelompoknya selama pembelajaran konsep mol ini.

Menentukan anggota kelompok dengan cara seperti ini ternyata membuat siswa lebih termotivasi dalam pembelajaran. Siswa menjadi tidak merasa bosan karena pembelajaran tidak hanya dilakukan di dalam kelas saja. Mereka harus berjalan keluar kelas dan mencari $Q R$ Code untuk dapat menemukan ketua kelompoknya.

Setelah dilakukan pembagian kelompok, siswa diminta untuk bekerja dalam kelompoknya mencari materi tentang konsep mol, mempelajarinya, membuat slide presentasi dan menyajikannya di hadapan teman-teman yang lain. Untuk kelas kontrol penyajian slide presentasi dilakukan dengan presentasi di depan kelas. Sedangkan pada kelas eksperimen siswa diwajibkan membuat slide presentasi dan memposting di beranda edmodo sehingga semua siswa dapat melihat dan berkomentar di kolom komentar.

Diskusi dalam kelas eksperimen dilakukan secara online. Cara ini memberikan kebebasan siswa untuk berpendapat. Berdasarkan penelitian, siswa terlihat nyaman dalam bertanya maupun berpendapat menggunakan bahasa siswa sehari-hari dan guru bisa melihat keaktifan siswa dalam berdiskusi tersebut. Hal ini sesuai dengan penelitian sebelumnya yang dilakukan oleh Tanduklangi (2019). Hal ini dikarenakan karena siswa sudah familiar dengan media sosial sehingga memiliki ketertarikan sendiri untuk menggunakannya. Adanya kolom komentar juga menimbulkan keinginan siswa untuk dapat memberikan komentar terhadap hasil pekerjaan temannya yang diposting pada beranda edmodo. Padahal, jika siswa tersebut ingin berkomentar dia harus tahu isi dari materi yang akan dia komentari. Hal tersebut membuat siswa termotivasi untuk memelajari isi materi 
yang diposting oleh temannya. Penelitian yang dilakukan oleh Dewi (2014) menyatakan beberapa siswa akan merasa lebih nyaman melakukan diskusi menggunakan edmodo karena mereka memiliki lebih banyak waktu untuk memikirkan jawaban dari pertanyaan temannya sebelum mereka membalasnya. Beberapa siswa yang merasa malu dan kurang peraya diri untuk berbiara di depan kelas juga lebih dapat mengekspresikan gagasannya dengan menulis di kolom komentar. Menurut Tiene (2000) dalam Tanduklangi (2019) pembelajaran online membuat siswa lebih tertarik dalam berdiskusi, berkomentar dan berinteraksi dengan guru maupun siswa lainnya sehingga diperaya dapat meningkatkan motivasi belajar siswa. Penelitian sejenis juga dilakukan oleh Komara (2014) yang menggunakan aplikasi edmodo dalam mata pelajaran Bahasa Inggris. Hasil penelitian menunjukkan penerapan aplikasi edmodo dapat memberikan motivasi belajar afektif, kognitif dan hubungan sosial.

\section{Hipotesis Kedua}

Berdasarkan hasil uji statistik didapatkan hasil bahwa ada perbedaan hasil belajar siswa yang menggunakan kolaborasi QRCE dan pembelajaran konvensional pada materi konsep mol. Dalam Gambar 4 dapat dilihat hasil belajar siswa pada kelas eksperimen mengalami peningkatan yang lebih signifikan dibanding kelas kontrol yang terdapat pada Gambar 3 . Hasil penelitian ini sesuai dengan hasil penelitian yang dilakukan oleh Wijayati, dkk. (2019) yang menerapkan pembelajaran berbasis digital ternyata dapat meningkatkan hasil belajar siswa sebesar 52,8\%.

Penerapan kolaborasi QRCE ternyata mampu membuat motivasi belajar siswa menjadi lebih baik sehingga membuat hasil belajarnya juga lebih baik. Menurut Damis dan Muhadjis (2018) motivasi sangat penting artinya dalam kegiatan belajar, sebab adanya motivasi mendorong semangat belajar dan sebaliknya kurang adanya motivasi akan melemahkan semangat belajar. Motivasi merupakan syarat mutlak dalam belajar; seorang siswa yang belajar tanpa motivasi (atau kurang motivasi) tidak akan berhasil dengan maksimal. Semakin tinggi motivasi belajar siswa maka akan semakin baik hasil belajarnya. Motivasi belajar yang tinggi membuat siswa akan lebih semangat dalam belajar sehingga lebih mudah dalam menguasai materi pembelajaran. Motivasi adalah hal yang sangat penting dalam proses pembelajaran yang berhubungan dengan hasil belajar siswa (Komara, 2014).

Hal ini juga dibuktikan dengan nilai usaha yang hasilnya positif dari seluruh siswa pada kelas ekserimen. Nilai usaha dihitung dengan cara memberikan tes kepada siswa sebanyak 3 kali. Dari hasil tes tersebut, dihitung nilai usaha siswa dengan menggunakan rumus:

Nilai usaha $=($ hasil tes $2-$ hasil tes 1$)+($ hasil tes 3 - hasil tes 2)

Jika didapatkan nilai positif artinya usaha siswa tersebut baik, namun jika nilainya negatif artinya usaha siswa tersebut menurun.

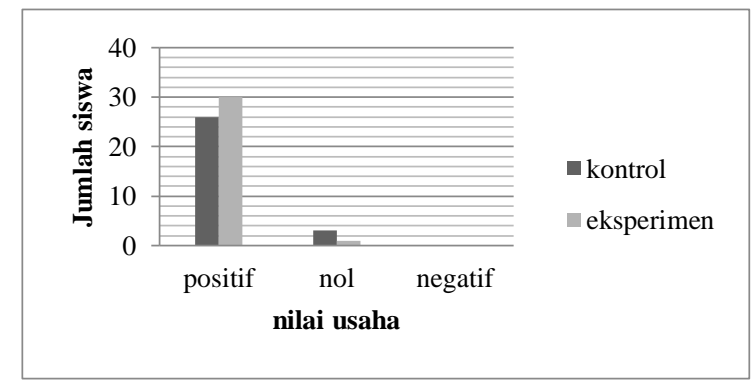

Gambar 5. Frekuensi Nilai Usaha Kelas Kontrol dan Eksperimen

Dari hasil perhitungan didapatkan nilai usaha untuk kelas kontrol 26 siswa memiliki nilai positif dan 3 siswa memiliki nilai 0 . Sedangkan untuk kelas ekperimen, 30 siswa memiliki nilai yang positif dan 1 siswa dengan nilai 0. Nilai usaha yang positif ini menunjukkan adanya kemauan dari siswa untuk memberikan hasil yang lebih baik.

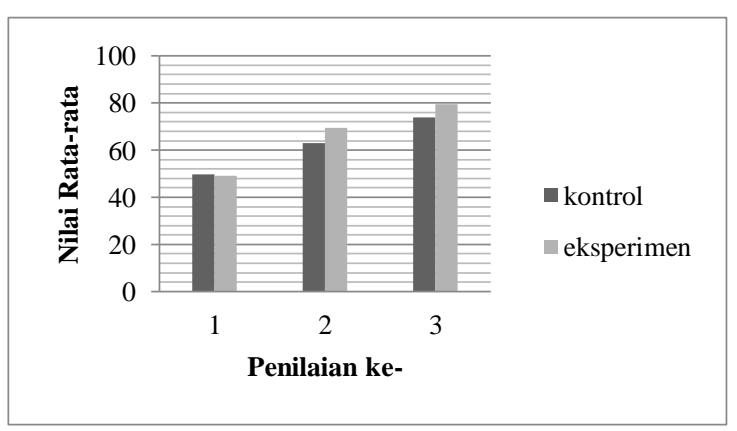

Gambar 6. Nilai Rata-rata Kelas Kontrol dan Eksperimen 
Berdasarkan diagram batang pada Gambar 6, dapat disimpulkan bahwa nilai ratarata tes siswa baik kelas kontrol maupun eksperimen meningkat namun peningkatan pada kelas eksperimen lebih signifikan. Hal ini sangat terlihat pada rata-rata tes pertama, nilai rata-rata kelas ekperimen sedikit lebih rendah daripada kelas kontrol, namun pada tes kedua nilai rata-rata kelas ekperimen lebih tinggi daripada kelas kontrol.

Peningkatan hasil belajar ini karena pembelajaran menggunakan edmodo merupakan proses pembelajaran antar anggota kelompok yang saling berinteraksi terhadap pengakuan tim dan tanggung jawab kelompok. Siswa merasa lebih nyaman mengeluarkan pendapat dan memberikan jawaban atas pertanyaan-pertanyaan dari siswa lain tanpa merasa takut salah, serta saling melengkapi pendapat teman untuk mendapatkan jawaban yang tepat. Kondisi ini dapat berdampak positif terhadap hasil belajar siswa.

Dalam pembelajaran dengan edmodo, siswa bekerja sama dalam suatu kelompok kecil yang kemampuannya berbeda untuk menyelesaikan tugas-tugas yang diberikan oleh guru. Tujuan dibentuk kelompok adalah untuk memberi kesempatan kepada siswa terlibat secara aktif dalam proses berpikir dan kegiatan belajar. Pada penelitian ini, peneliti membagi kelompok secara permanen. Kelompok yang lebih permanen dapat menghemat waktu, memudahkan pengelolaan kelas dan meningkatkan semangat saling membantu karena siswa saling mengenal dengan cukup baik dan terbiasa dengan cara belajar dengan teman sendiri (Wijayati, dkk., 2019). Selain itu, dalam Teori belajar Vygotsky atau yang sering disebut teori belajar sosiokultur menekankan pada bagaimana seseorang belajar dengan bantuan orang lain dalam suatu zona keterbatasan dirinya yaitu zona proksimal development (ZPD) atau zona perkembangan proksimal dan mediasi. Pada zona ini anak dalam perkembangannya membutuhkan orang lain untuk memahami sesuatu dan memecahkan masalah yang dihadapinya (Rahmadonna, 2010). Teori yang juga disebut sebagai teori konstruksi sosial ini menekankan bahwa proses pembangunan pengetahuan merupakan interaksi sosial yang berasal dari masyarakat, lingkungan dan budayanya. Teori ini juga menegaskan bahwa perolehan kognitif individu terjadi pertama kali melalui interpersonal (interaksi dengan lingkungan sosial) dan intrapersonal (internalisasi yang terjadi dalam diri sendiri) (Eberlein, et al., 2008; Rahmadonna, 2010). Dalam kelas kontrol maupun eksperimen, siswa diberi kesempatan untuk bekerjasama dalam kelompok. Namun siswa di kelas ekserimen merasa lebih nyaman dalam mengungkapkan pendapat dan pengetahuannya, sehingga lebih banyak hal yang dapat disampaikan. Hal ini lah yang memberikan pengaruh positif terhadap hasil belajar siswa.

\section{Simpulan, Saran, dan Rekomendasi}

\section{Kesimpulan}

Berdasarkan analisis data dan pembahasan yang telah dilakukan dapat disimpulkan bahwaterdapat perbedaan motivasi dan hasil belajar siswa yang menggunakan kolaborasi QRCE dan pembelajaran konvensional pada mata pelajaran kimia materi konsep mol.

\section{Saran}

Saran dari peneliti bahwa pembelajaran menggunakan kolaborasi QRCE dapat digunakan pada materi lain dalam kimia atau mata pelajaran lain. Tetapi guru dan siswa harus dibekali kemampuan menggunakan smartphone, serta dukungan dari lingkungan sekolah, seperti koneksi internet yang baik agar penerapannya lebih optimal untuk pembelajaran.

\section{Rekomendasi}

Dalam menerapkan model pembelajaran dicovery, peneliti harus mempersiapkan pertanyaan-pertanyaan yang mengarahkan siswa untuk dapat menemukan konsep yang ingin dipelajari.

Perlu dilakukan penelitian dengan faktor internal selain motivasi belajar.

\section{Daftar Pustaka}

Amri Tanduklangi, Asrun Lio dan Alberth. (2019). Classroom Action Research In Teaching English For Senior High School Students Through Blended Learning In Kendari Of Indonesia. Journal of e-Learning and Knowledge Society Je-LKS. The Italian eLearning Association Journal Vol. 15, n.1, 2019 ISSN: 1826-6223 | eISSN: 1971-8829 
Damis Dan Muhajis (2018) Analisis Hubungan Antara Motivasi Belajar Dengan Hasil Belajar Siswa Pada Sekolah Dasar Negeri 3 Allakuang Kecamatan Maritengngae Kabupaten Sidenreng Rappang. Jurnal Idaarah, Vol. Ii, No. 2, Desember 2018

Darmawan. (2018, November 27). Menjadi Guru Era Pendidikan 4.0. serambinews.com. https://aceh.tribunnews.com/2018/11/27/me njadi-guru-era-pendidikan-40.

Eberlein, T, Kampmeler, J, Minderhout, V, Moog, RS, Plat, T, Nelson, PV, dan White, HB. 2008. Pedagogies of Engagement in Science A comparison of PBL, POGIL, and PLTL. Biochemistry and Molecular Biology Education. Volume 36(4), 262-273.

Finita Dewi. (2014). EDMODO: A Social Learning Platform for Blended Learning Class in Higher Education. Research in Education Technology: Pedagogy and Technology Journal. SEAMEO-SEAMOLEC. Vol $X I /$ No.2/2014

Houda Salim Al-Ruheili dan Asiya Abdallah AlSaidi (2015). Students' Perceptions on the Effectiveness of Using Edmodo in EFL Classes. GAI Istanbul International Academic Conference Proceedings

Hourdequin, P. (2014). Edmodo: A Simple Tool for Blended Learning. The Language Teacher 38.

Kandappan Balasubramanian, Jaykumar V, dan Leena Nitin Fukey. (2014). A study on
"Student preference towards the use of Edmodo as a learning platform to create responsible learning environment". Procedia - Social and Behavioral Sciences 144 ( 2014 ) 416 - 422 .

Marie Ebifagha Zakana dan Esther Fomsi F. (2019). Effect of Social Networking Sites on Students'Engagement and Motivation in Computer Science inBayelsa State, Nigeria. European Scientific Journal February 2019 edition Vol.15, No.5 ISSN: 1857 - 7881 (Print) e - ISSN 1857- 7431

Nanik Wijayati, Ersanghono Kusuma, dan Sri Susilogati Sumarti. (2019). Pembelajaran Berbasis Digital Di Jurusan Kimia FMIPA UNNES. Jurnal Inovasi Pendidikan Kimia, Vol 13, No 1, 2019, halaman 2318 - 2325

Narayanan, A.S. (2012). QR Code and security solution. International Journal of Computer Science and Telecommunications, 3(7), 6971.

Rahmadonna, S. 2010. Teori Belajar Sosiokultur (Lev Vygotsky). Makalah.

Ridwan, Dkk. (2010). Mengamankan single identity number (SIN) menggunakan QR code dan sidik jari. Internet Working Indonesia Journal, 2(2), 17-20.

U. Komara dan Junjun Muhamad Ramdani. (2014). Motivating Students Through Edmodo (A Blended Learning in Grammar Class). The 61 TEFLIN International Conference, UNS Solo 2014 